\title{
REVIEW
}

\section{Lysogenic and lytic viral production in marine microbial communities}

\author{
William H. Wilson*, Nicholas H. Mann \\ Department of Biological Sciences, University of Warwick, Coventry CV4 7 AL, United Kingdom
}

\begin{abstract}
It is now well established that viruses are an abundant component of marine ecosystems and they are being increasingly recognised and accepted as important contributors to element cycling within the microbial loop. However, some of the key questions regarding the ecological significance of viruses in the marine environment still remain largely unanswered. Thus, particular interest is currently focused on the extent to which lytic production or lysogeny predominates and the nature of factors in the marine environment, particularly nutrient availability and multiplicity of infection (MOI), which might influence the lysis/lysogeny 'decision' The present evidence is still insufficient to unambiguously assess the relative ecological significance of lysogeny versus lysis and progress in this area will rely on the development and application of new techniques. This review attempts to collect recent information relating to this central question, focusing particularly on those viruses which infect the bacterioplankton and nano- and picophytoplankton.
\end{abstract}

KEY WORDS: Viruses $\cdot$ Lysogeny $\cdot$ Nutrient limitation $\cdot$ MOI $\cdot$ Phosphate $\cdot$ Phytoplankton $\cdot$ Bacteria

\section{INTRODUCTION}

Viruses in the marine environment are being increasingly recognised and accepted as important contributors to element cycling within the microbial loop A variety of approaches have been used to characterise the viruses which infect members of the bacterioplankton and phytoplankton, and to establish their temporal abundance and ecological significance. These approaches range from the conventional microbiological techniques to the use of the transmission electron microscope (TEM), the most widely used tool (e.g. Børsheim et al. 1990), DNA-specific fluorescent stains (e.g. Hennes et al. 1995), radiolabelled probes (e.g. Steward et al. 1992a, 1996, Fuhrman \& Noble 1995) and more recently, virus-specific DNA probes (e.g. Chen et al. 1996). Despite the application of these techniques, the ecological impacts of viruses within oceanic environments remain largely unquantified.

·E-mail:wl@dna.bio.warwick.ac.uk
In this review we address the question of what factors influence the lysis/lysogeny decision, and review some of the new techniques recently being developed which could ultimately be used to answer this question. Much of the information discussed relates to bacteriophages infecting either the bacterioplankton or prokaryotic components of the picophytoplankton (e.g. cyanobacterial Synechococcus strains). However, where possible, viruses infecting eukaryotic species of phytoplankton are also considered. Indeed, the majority of concepts and techniques may be equally applicable to both groups of viruses.

\section{VIRAL REPLICATION, LYSIS OR LYSOGENY?}

There are 2 predominant mechanisms of bacteriophage replication, lysis and lysogeny, and the relative importance of each in the marine environment is currently unknown and subject to considerable speculation, as are the environmental factors which determine 
whether lysogeny is established or whether lysogens re-enter the lytic cycle. Furthermore, Iysis/lysogeny will be important factors in the potential for the genetic exchange, and in this context horizontal gene transfer by marine lysogenic bacteriophages has recently been demonstrated (Chiura \& Takagi 1994, Chiura \& Kato 1996).

It is often stated that $90 \%$ of viruses are temperate (Freifelder 1987), however, the present limited knowledge of relevant bacteriophage-host systems does not permit such a generalisation to be made for the marine environment. It is known that many bacteriophages occurring in aqueous environments are temperate. Approximately $4 \%$ of Escherichia coli isolates from sewage and faeces are lysogenic (Dhillon \& Dhillon 1981) as are many strains of lactic acid streptococci used in cheese making (Jarvis et al. 1978) and a temperate bacteriophage has been recently isolated which lysogenizes the marine cyanobacterium Phormidium persicinum (Ohki \& Fujita 1996).

Induction of the lytic cycle commonly occurs following stimulation of the lysogenic cell by an environmental factor such as ultraviolet light or other DNAdamaging agents, although it has been recently demonstrated that polyaromatic hydrocarbons may induce lysogenic marine microbial communities (Jiang \& Paul 1996). In surface seawater, ultraviolet light is not widely held to be a significant factor in inducing lysogenic bacteriophages, in contrast to many previously well-characterised phage-host systems. It has been demonstrated that direct sunlight has no effect on virus production in coastal seawater incubated in clear polyethylene bags (Wilcox \& Fuhrman 1994), however, viral decay rates are known to dramatically increase following exposure to direct sunlight (Suttle \& Chen 1992, Noble \& Fuhrman 1997). Changes in temperature acting as an inducing factor have only been observed with specifically isolated temperature-sensitive mutants from enteric host-phage systems (e.g. Edgar \& Lielausis 1964) and consequently it seems unlikely that temperature per se will exert a significant effect on the termination of lysogeny in the marine environment

Several studies have reported on the relative importance of lysis and lysogeny in the marine environment. Jiang \& Paul (1994) screened 51 bacterial isolates, from a variety of coastal and oceanic environments, for the presence of inducible prophages and discovered that 22 isolates were either lysogenic or bacteriocinogenic and that Iysogeny was more frequent in offshore isolates than in isolates from more nutrient-rich coastal environments. However, only bacterial strains which were culturable were utilised in this study and consequently may not be representative of the bacterial community as a whole. Wilcox \& Fuhrman (1994) demonstrated that when they exposed natural bacterial communities to continuous sunlight, lytic infection, rather than the induction of lysogens, was responsible for the majority of bacteriophage production in coastal seawater. During a similar study in the Gulf of Mexico, Weinbauer \& Suttle (1996) used mitomycin C and UV-C radiation (wavelength $254 \mathrm{~nm}$ ) to induce lysogens in natural communities of bacteria and estimated that only 0.07 to $4.4 \%$ of the total bacterial population were lysogenic. Moreover, they found no significant difference between oligotrophic water in the centre of the Gulf of Mexico and shelf waters off the Texan coast (USA). In contrast, Jiang \& Paul (1996) observed that a much higher proportion (average $34 \%$ ) of an estuarine bacterial population was lysogenized when they used a variety of inducing aggents: these included mitomycin C: UV radiation, sunlight, temperature, pressure and polyaromatic hydrocarbons. Different approaches have been used in each of the above studies to determine the relative importance of lysogenic or lytic viral production in various ocanic environments, therefore, it is not surprising that results differ among investigators.

Classically, 2 principal factors determine whether a temperate phage establishes lysogeny, namely nutritional conditions and multiplicity of infection (MOI). In the majority of cases examined, high MOI favours lysogeny and low MOI promotes lysis. Indeed, there may also be interactions between the 2 parameters with nutritional conditions determining the MOI required for lysogenization (see Herskowitz \& Banuett 1984).

\section{NUTRITIONAL CONDITIONS}

Kokjohn et al. (1991) observed that a phage infecting starved host $P$ seudomonas aeruginosa cells, developed a pseudolysogenic relationship. A greater frequency of lysogens has been observed in bacteria isolated from the offshore environment (lower nutrient conditions) compared to more nutrient-rich coastal environments (Jiang \& Paul 1994). In contrast, Jiang \& Paul (1996) observed that prophage induction occurred more frequently from natural bacterial populations in coastal and estuarine environments than offshore environments.

Several studies have implicated phosphate as the principal trigger responsible for the switch from lytic production to lysogeny. Wilson et al. (1996) demonstrated that, following cyanophage infection, only 9.3\% of phosphate-depleted infected Synechococcus sp. WH7803 (a marine phycoerythrin-containing cyanobacterium) cells lysed in contrast to $100 \%$ of infected phosphate-replete cells, and it was suggested that marine cyanophages may establish lysogeny in response 
to phosphate-depleted growth of host cells. Bratbak et al. (1993) demonstrated, in mesocosm enclosures in a Norwegian fjord, that restricted phosphate availability inhibited the development of viruses in Emiliania huxleyi, a marine coccolithophorid, while nitrate availability appeared to have no effect on virus development. They suggested that viruses may be more sensitive to phosphorus limitation than nitrate limitation since viruses have a high nucleic acid to protein ratio. Tuomi et al. (1995) demonstrated that when phosphate was added back to phosphate-depleted seawater (2.5 l volume) there was a significant drop in bacterial abundance; they suggested that 1 sub-population of bacteria lysed when viral activity was stimulated by an increase in phosphate availability and that increased nutrient availability induced temperate viruses from lysogenic bacterial populations.

During a seawater mesocosm enclosure experiment, Wilson et al. (1997) observed that there was an apparent collapse of a Synechococcus spp. bloom, following phosphate addition to a phosphate-limited enclosure, and came to similar conclusions as Tuomi et al. (1995). However, in contrast, Wikner et al. (1993) demonstrated that nucleic acids from host cells are the major source of nucleotides for marine bacteriophages (cf. Teven phages of enteric bacteria which derive phage DNA phosphorus from the surrounding medium; Kozloff \& Putnam 1950), suggesting that marine bacteriophages should not be especially sensitive to phosphate limitation. Wikner et al. (1993) proposed that this metabolic strategy may be common among marine viruses as an adaptation to a nutrient-deficient environment. Although these reports appear contradictory in their conclusions, there does seem to be a link between the supply of phosphate and viral infection kinetics in seawater. However, it should be noted that no definitive experiments have been done to examine the significance of nutrients as a trigger in natural marine communities.

\section{MULTIPLICITY OF INFECTION (MOI)}

There is no direct evidence to suggest that MOI determines the establishment of lysogeny in the marine environment. It is extremely difficult to calculate MOI values in situ without the ability to recognise subsets of the microbial community that are susceptible to infection by viruses. Fluorescently labelled virus probes have been used to identify and quantify groups of bacteria in mixed microbial communities (Hennes et al. 1995), however, this technology has not been applied to determine $\mathrm{MOI}$ in these communities. Further studies will need to be performed on established virus/host systems in culture although many of these systems will select for predominantly lytic viruses. Using a more indirect approach, correlation studies indicate that there is a higher virus to bacteria ratio (VBR) in eutrophic waters as compared to more oligotrophic waters (for review see Bratbak \& Heldal 1995). If MOI values are directly inferred from the VBR using this information, then it would indicate that there is a higher $\mathrm{MOI}$ in eutrophic waters compared to more oligotrophic waters; hence, lysogeny might be favoured in eutrophic conditions (as observed by Jiang \& Paul 1996).

In a study of the interactions between marine Synechococcus spp. populations and cyanophages across a transect in the Gulf of Mexico, Suttle \& Chan (1994) demonstrated that lytic cyanophages lysed a significant portion of the Synechococcus population on a daily basis. In addition, these workers demonstrated that there was a threshold in the Synechococcus abundance of ca $10^{3}$ cells $\mathrm{ml}^{-1}$, above which the concentration of infectious cyanophages increased 100 -fold and cyanophage concentrations often exceeded those of their hosts. Presumably MOI will increase during these conditions hence, increasing the proportion of lysogenic Synechococcus host cells. A similar observation was made with the eukaryotic phytoplankter Micromonas pusilla and its corresponding virus $M p V$, during a field study in coastal water in the Gulf of Mexico (Cottrell \& Suttle 1995a). A stable coexistence of $M$. pusilla and the lytic virus was observed and viral abundance was greater than that of its host. In a similar study in coastal water off the north-eastern United States, Waterbury \& Valois (1993) suggested that Synechococcus communities are dominated by cells resistant to their co-occurring phages, and that these lytic phages are maintained by infecting the relatively rare sensitive cells in these communities. Waterbury \& Valois (1993) consequently suggested that sensitive cells persist as a minority population because they possess a growth advantage over their resistant counterparts. Resistance to the predominant co-occurring phages could arise through 2 primary mechanisms. Firstly, resistance might occur as a result of mutation leading to loss of the phage receptor. Phage receptors, where characterised, are commonly components of nutrient transport systems (for reviews see Konisky 1979, Heller 1992) and consequently such mutants would be impaired for growth and explain why their phagesensitive counterparts are maintained in the population. Secondly, it is known that lysogenic host cells may confer superinfection immunity to closely related viruses thus preventing further infection. Hence, lysogenic cells may predominate in the Synechococcus population as the MOI increases throughout the bloom.

In contrast to systems where there is a co-existence of the virus and its host, some phytoplankton species exhibit sudden and dramatic bloom collapses in which 
viruses have been implicated. It has been well documented that the collapse of Emiliania huxleyi blooms is associated with a large increase in virus abundance (Bratbak et al. 1993, Brussaard et al. 1996, Wilson et al. 1997) and the collapse of blooms of the red tide alga Heterosigma akashiwo have also been attributed to viruses (Nakasaki et al. 1994a, b). The discovery of a virus infecting the nuisance-bloom alga Phaeocystis (Jacobsen et al. 1996) may explain the collapse of spring blooms of this organism (van Boekel et al. 1992). It is unclear what mechanisms are involved in the virus-induced collapse of these blooms. It has been suggested that lysogenic/latent viruses are induced by an environmental 'trigger' towards the end of the bloom, however, the nature of this trigger is still unknown. The large increase in free viruses following the collapse of a bloom will undoubtedly result in a high MOI, hence ensuring that remaining 'seed' populations of phytoplankton are lysogemic/latent.

\section{DEVELOPMENT OF NEW TECHNIQUES FOR STUDYING VIRAL ECOLOGY}

Traditional methods of estimating virus abundance and productivity have relied primarily on TEM (Børsheim et al. 1990, Proctor \& Fuhrman 1990), however, TEM analysis can be very laborious and time consuming. Radiotracer analysis, a promising new tool for measuring virus productivity, was developed by Steward et al. (1.992b), however, there were initial problems with inaccuracy due to variable and potentially biased losses of viruses. The incorporation of radiotracers ${ }^{32} \mathrm{P}$ orthophosphate and ${ }^{3} \mathrm{H}$-thymidine into viral particles has since been used successfully (Steward et al. 1992a, 1996, Fuhrman \& Noble 1995) where results were comparable to similar studies using TEM analysis to estimate virus production (e.g. Weinbauer et al. 1993). Other methods have included inhibition experiments (Heldal \& Bratbak 1991, Bratbak et al, 1992), where new virus production was inhibited by the addition of potassium cyanide, however, this resulted in overestimation of virus production. Measurement of dissolved esterase activity in seawater has also been used as an indirect indicator of viral production via phytoplankton lysis (Brussaard et al. 1995). The main disadvantage with each of the methods mentioned above is lack of specificity. It is difficult to attribute specific roles to individual viruses if they are always studied as a diverse, mixed population where different host/virus systems may interact completely differently within a given environment.

In an attempt to study specific virus populations, Hennes et al. (1995) successfully used fluorescently stained viruses as probes to interrogate specific bacte- ria and cyanobacteria in mixed microbial communities. These workers used the brightly fluorescent cyaninebased dyes, YOYO-1 and POPO-1, which have very high binding co-efficients for nucleic acids (Hirons et al. 1994) and can be used to stain and visualise individual viruses by epifluorescence microscopy (Hennes $\&$ Suttle 1995). With the recent advent of the application of these dyes to the enumeration of marine bacterial populations, using flow cytometry (Li et al. 1995, Marie et al. 1996), there now exists the possibility for the simultaneous enumeration of specific infective viruses. Enteric bacteriophages (Hercher et al. 1979), large fragments of fluorescently labelled DNA (Goodwin et al. 1993), HIV-1 DNA and mRNA in HIV-1infected cells (Patterson et al. 1993), and HIV-1 antigens in cells positive for HIV-1 (Holzer et al. 1993) have all been detected by flow cytometry; therefore, detection of fluorescently labelled viruses by flow cytometry constitutes an attractive method for rapidly detecting and enumerating virus/host interactions in seawater.

Finally, the most promising approaches for assessing the significance and frequency of lysogeny in the marine environment are based on the application of molecular techniques. Several methods have been developed to detect human enteric viruses in environmental samples, including the coastal marine environment; this constitutes an area of research extensively funded by public health organisations. Approaches using gene probes have been used (Gerba et al. 1989, Ogunseitan et a1. 1992). However, most of the methods for detecting human enteric viruses in the marine environment are based on polymerase chain reaction (PCR) technology (Straub et al. 1994; for reviews, see Lopez-Pila et al. 1993, Sobsey 1993) and its derivatives, e.g. reverse transcriptase PCR (Tsai et al. 1993, 1994, 1995, Gilgen et al. 1995) and antigen capture PCR (Graff et al. 1993). Similar methods have only very recently been used to interrogate oceanic virus populations. Early molecular studies looked at the clonal variation between isolated viruses such as Micromonas pusilla Virus (MpV) and marine cyanophages (Cottrell \& Suttle 1991, Wilson et al. 1993 respectively). Subsequent studies have centred on looking at the genetic diversity of specific groups of viruses (Cottrell \& Suttle 1995b, Kellog et al. 1995) and phylogenetic analysis between different genera of viruses using nested PCR with degenerate primers based on DNA polymerase genes sequenced from viruses which infect 3 genera of microalgae (Chen \& Suttle 1995, 1996, Chen et al. 1996). Results from such studies demonstrate that viruses which infect members of marine microbial communities are diverse and widely distributed. Molecular analyses will undoubtedly permit the study of individual virus populations and the assessment of their impact on host 
populations and may thus allow an accurate evaluation of the factors affecting the lysis/lysogeny 'decision' and its ecological significance for oceanic microbial communities.

Acknowledgements. The emphasis of this review reflects the focus of discussions at a workshop entitled 'Viruses and the viral loop' held at the 5th European Marine Microbiology Symposium (5EMMS) in Bergen, Norway. We thank the invaluable contributions of all the participants during this workshop. The comments of 3 referees are appreciated and helped to improve the manuscript. This is PRIME contribution number 27 .

\section{LITERATURE CITED}

Børsheim Y, Bratbak G, Heldal M (1990) Enumeration and biomass estimation of planktonic bacteria and viruses by transmission electron microscopy. Appl Environ Microbiol $56: 1400-1405$

Bratbak G, Egge JK, Heldal M (1993) Viral mortality of the marine alga Emiliania huxleyi (Haptophyceae) and termination of algal blooms. Mar Ecol Prog Ser 93:39-48

Bratbak G, Heldal M (1995) Viruses - the new players in the game; their ecological role and could they mediate genetic exchange by transduction? In: Joint I (ed) Molecular eco]ogy of aquatic microbes. NATO ASI Series Vol G38. Springer-Verlag, Berlin, p 249-264

Bratbak G, Heldal M, Thingstad TF, Riemann B, Haslund $\mathrm{OH}$ (1992) Incorporation of viruses into the budget of microbial C-transfer. A first approach. Mar Ecol Prog Ser 83: 273-280

Brussaard CPD, Kempers RS, Kop AJ, Reigman R, Heldal M (1996) Virus-like particles in a summer bloom of Emiliania huxleyi in the North Sea. Mar Ecol Prog Ser 10:105-113

Brussaard CPD, Riegman R, Noordeloos AAM, Cadee GC, Witte $H$, Kop AJ, Nieuwland G, van Duyl FC, Bak RPM (1995) Effects of grazing, sedimentation and phytoplankton cell lysis on the structure of a coastal pelagic food web. Mar Ecol Prog Ser 123:259-271

Chen F, Suttle CA (1995) Amplification of DNA polymerase gene fragments from viruses infecting microalgae. Appl Environ Microbiol 61:1274-1278

Chen F, Suttle CA (1996) Evolutionary relationships among large double-stranded DNA viruses which infect microalgae and other organisms, as inferred from DNA polymerase genes. Virology 219:170-178

Chen F, Suttle CA, Short SM (1996) Genetic diversity in marine algal communities as revealed by sequence analysis of DNA polymerase genes. Appl Environ Microbiol 62: 2869-2874

Chiura HX, Kato K (1996) Viruses - a possible function of gene transfer in aquatic systems. Programme and $a b-$ stracts of the 5th European Marine Microbiology Symposium, Bergen, p 32

Chiura HX, Takigi J (1994) Phage-like particles production and gene transfer by marine bacteria. Bull Jpn Soc Microb Ecol 9:75-90

Cottrell MT, Suttle CA (1991) Wide-spread and clonal variation in viruses which causes lysis of a cosmopolitan, eukaryote marine phytoplankter, Micromonas pusilla. Mar Ecol Prog Ser 78:1-9

Cottrell MT, Suttle CA (1995a) Dynamics of a lytic virus infecting the photosynthetic marine picoflagellate Micromonas pusilla. Limnol Oceanogr 40:730-739
Cottrell MT, Suttle CA (1995b) Genetic diversity of algal viruses which lyse the photosynthetic picoflagellate Micromonas pusilla (Prasinophyceae). Appl Environ Microbiol 61:3088-3091

Dhillon TS, Dhillon EKS (1981) Incidence of lysageny, colicinogeny, and drug resistance in enterobacteria isolated from sewage and from rectum of humans and some domesticated species. Appl Environ Microbiol 41:894-902

Edgar RS, Lielausis I (1964) Temperature sensitive mutants of phage T4D: their isolation and genetic characterisation. Genetics 49:649-662

Freifelder D (1987) Molecular biology: a comprehensive introduction to prokaryotes and eukaryotes. Jones and Bartlett Publishers Inc, Boston, p 665-700

Fuhrman JA, Noble RT (1995) Viruses and protists cause similar bacterial mortality in coastal seawater. Limnol Oceanogr 40:1236-1242

Gerba CP, Margolin AB, Hewlett MJ (1989) Application of gene probes to virus detection in water Water Sci Technol 21:147-154

Gilgen M, Wegmuller B, Burkhalter P, Buhler HP, Muller U, Luthy J, Candrian U (1995) Reverse transcription PCR to detect enteroviruses in surface water. Appl Environ Microbiol 61:1226-1231

Goodwin PM, Johnson ME, Martin JC, Ambrose WP, Marrone BL, Jett JH, Keller RA (1993) Rapid sizing of individual fluorescently stained DNA fragments by flow cytometry. Nucleic Acids Res 21:803-806

Graff J, Ticehurst J, Flehmig B (1993) Detection of Hepatitis A virus in sewage sludge by antigen capture polymerase chain reaction. Appl Environ Microbiol 59:3165-3170

Heldal M. Bratbak G (1991) Production and decay of viruses in aquatic environments. Mar Ecol Prog Ser 72:205-212

Heller KJ (1992) Molecular interaction between bacteriophage and the Gram-negative cell envelope. Arch Microbiol 158:235-248

Hennes KP, Suttle CA (1995) Direct counts of viruses in natural seawater and laboratory cultures by epifluorescence microscopy. Limnol Oceanogr 40:1054-1059

Hennes KP, Suttle CA, Chan AM (1995) Fluorescently labelled virus probes show that natural virus populations can control the structure of marine microbial communities. Appl Environ Microbiol 61:3623-3627

Hercher M, Mueller W, Shapiro HW (1979) Detection and discrimination of individual viruses by flow cytometry. J Histochem Cytochem 27:350-352

Herskowitz I, Banuett F (1984) Interaction of phage, host, and environmental factors in governing the $\lambda$ lysis-lysogeny decision. In: Chopra VL, Joshi BC, Sharma RP, Bansal HC (eds) Proceedings of the XV international congress of genetics, Vol 1. Oxford and 1.B.H., New Delhi, p 59-73

Hirons GT, Fawcett JJ, Crissman HA (1994) TOTO and YOYO: new very bright fluorochromes for DNA content analysis by flow cytometry. Cytometry 15:129-140

Holzer TJ, Heynen CA, Novak RM, Pitrak DL, Dawson GJ (1993) Frequency of cells positive for HIV-1 p24 antigen assessed by flow cytometry. AIDS 7 (suppl 2):S3-S5

Jacobsen A, Bratbak G, Heldal M (1996) Isolation and characterization of a virus infecting Phaeocystis pouchetii (Prymnesiophyceae). J Phycol 32:923-927

Jarvis AW, Heap HA, Lawrence RC (1978) The origin of bacteriophages in cheese factories. In: Loutit MW, Miles JAR (eds) Microbial ecology. Springer-Verlag, Berlin, p $438-442$

Jiang SC, Paul JH (1994) Seasonal and diel abundance of viruses and occurrence of lysogeny/bacteriocinogeny in the marine environment. Mar Ecol Prog Ser 104:163-172 
Jiang SC, Paul JH (1996) Occurrence of lysogenic bacteria in marine microbial communities as determined by prophage induction. Mar Ecol Prog Ser 142:27-38

Kellog CA, Rose JB, Jiang SC. Thurmond JM, Paul JH (1995) Genetic diversity of related vibriophages isolated from marine environments around Florida and Hawaii, USA. Mar Ecol Prog Ser 120:89-98

Kokjohn TA, Sayler GS, Miller RV (1991) Attachment and replication of Pseudomonas aeruginosa bacteriophages under conditions simulating aquatic environments. J Gen Microbiol 137:661-666

Konisky J (1979) Specific transport systems and receptors for colicins and phages. In: Inouye $M$ (ed) Bacterial outer membranes: biogenisis and functions. John Wiley and Sons, New York, p 319-359

Kozloff LM, Putnam FW (1950) Biochemical studies of virus reproduction: III. The origin of virus phosphorus in the Escherichia coli $\mathrm{T}_{6}$ bacteriophage system. J Biol Chem 182:229-243

Li WKW, Jellet JF, Dickie PM (1995) DNA distributions in planktonic bacteria stained with TOTO or TO-PRO. Limnol Oceanogr 40:1485-1495

Lopez-Pila JM, Krawelitzki B, Hachula G, Sheler C. Kopecka $H$ (1993) Detection of viruses in water and soil by molecular hybridisation techniques and by PCR: pitfalls and limitations. In: Guerrero R, Pedros-Alio $C$ (eds) Trends in microbial ecology. Spanish Society for Microbiology, Barcelona, p 595-600

Marie D, Vaulot D, Partensky F (1996) Application of the novel nucleic acid dyes YOYO-1, YO-PRO-1, and PicoGreen for flow cytometric analysis of marine prokaryotes. Appl Environ Microbiol 62:1649-1655

Nagasaki K, Ando M, Imai I, Itakura S, Ishida Y (1994a) Viruslike particles in Heterosigma akashiwo (Raphidophyceae): a possible red tide disintegration mechanism. Mar Biol 119:307-312

Nagasaki K, Ando M, Itakura S, Imai I, Ishida Y (1994b) Viral mortality in the final stages of Heterosigma akashiwo (Raphidophyceae) red tide. J Plankton Res 16:1595-1599

Noble RT, Fuhrman JA (1997) Virus decay and its causes in coastal waters. Appl Environ Microbiol 63:77-83

Ogunseitan OA, Sayler GS, Miller RV (1992) Application of DNA probes to analysis of bacteriophage distribution patterns in the environment. Appl Environ Microbiol 58: $2046-2052$

Ohki K, Fujita Y (1996) Occurrence of a temperate cyanophage lysogenizing the marine cyanophyte Phormidium persicinum. J Phycol 32:365-370

Patterson BK, Till M, Otto P, Goolsby C, Furtado MR, McBride LJ, Wolinsky SM (1993) Detection of HIV-1 DNA and messenger RNA in individual cells by PCR-driven in situ hybridisation and flow cytometry. Science 260:976-979

Proctor LM. Fuhrman JA (1990) Viral mortality of marine bacteria and cyanobacteria. Nature 343:60-62

Sobsey MD (1993) The use of molecular techniques for the detection of viruses in environmental samples. In: Guerrero $R$, Pedros-Alio $C$ (eds) Trends in microbial ecology. Spanish Society for Microbiology, Barcelona, p 601-606

Steward GF, Smith DC, Azam F (1996) Abundance and production of bacteria and viruses in the Bering and Chukchi Seas. Mar Ecol Prog Ser 131:287-300

Steward GF, Wikner J, Cochian WP, Smith DC, Azam F (1992a) Estimation of virus production in the sea: Il. Field results. Mar Microb Food Webs 6:79-90

Responsible Subject Editor: G. Bratbak, Bergen, Norway
Steward GF, Wikner J, Smith DC, Cochlan WP, Azam F (1992b) Estimation of virus production in the sea: I. Method development. Mar Microb Food Webs 6:57-78

Straub TM, Pepper IL. Abbaszadegan M, Gerba CP (1994) A method to detect enteroviruses in sewage sludgeamended soil using the PCR. Appl Environ Microbiol 60: 1014-1017

Suttle CA, Chan AM (1994) Dynamics and distribution of cyanophages and their effect on marine Synechococcus spp. Appl Environ Microbiol 60:3167-3174

Suttle CA, Chen F (1992) Mechanisms and rates of decay of marine viruses in seawater. Appl Environ Microbiol 58: $3721-3729$

Tsai YL, Sobsey MD, Sangermano LR, Palmer CJ (1993) Simple method of concentrating enteroviruses and hepatitis $A$ from sewage and ocean water for rapid detection by reverse transcriptase-polymerase chain reaction. Appl Environ Microbiol 59:3488-3491

Tsai YL, Tran B, Palmer CJ (1995) Analysis of viral RNA persistence in seawator by reverse transcriptase-PCR Apnl Environ Microbiol 61:363-366

Tsai YL, Tran B, Sangermano LR, Palmer CJ (1994) Detection of poliovirus, hepatitis A virus and rotavirus from sewage and ocean water by triplex reverse transcriptase PCR. Appl Environ Microbiol 60:2400-2407

Tuomi P, Fagerbakke KM, Bratbak G. Heldal M (1995) Nutritional enrichment of a microbial community: the effects on activity, elemental composition, community structure and virus production. FEMS Microb Ecol 16:123-134

van Boekel WHM, Hansen FC, Riegman R, Bak RPM (1992) Lysis-induced decline of a Phaeocystis spring bloom and coupling with the microbial foodweb. Mar Ecol Prog Ser 81:269-276

Waterbury JB, Valois FW (1993) Resistance to co-occurring phages enables marine Synechococcus communities to coexist with cyanophages abundant in seawater. Appl Environ Microbiol 59:3393-3399

Weinbauer MG, Fuks D, Peduzzi P (1993) Distribution of viruses and dissolved DNA along a coastal trophic gradient in the northern Adriatic Sea. Appl Environ Microbiol 59:4074-4082

Weinbauer MG, Suttle CA (1996) Potential significance of lysogeny to bacteriophage production and bacterial mortality in coastal waters of the Gulf of Mexico. Appl Environ Microbiol 62:4374-4380

Wikner J, Vallino JJ, Steward GF, Smith DC, Azam F (1993) Nucleic acids from the host bacterium as a major source of nucleotides for three marine bacteriophages. FEMS Microb Ecol 12:237-248

Wilcox RM, Fuhrman JA (1994) Bacterial viruses in coastal seawater: lytic rather than Iysogenic production. Mar Ecol Prog Ser 114:35-45

Wilson WH, Carr NG, Mann NH (1996) The effect of phosphate status on the kinetics of cyanophage infection in the oceanic cyanobacterium Synechococcus sp. WHF803. J Phycol 32:506-516

Wilson WH, Joint IR, Carr NG, Mann NM (1993) Isolation and molecular characterisation of five marine cyanophages propagated on Synechococcus sp. WH 7803. Appl Environ Microbiol 59:3736-3743

Wilson WH, Turmer S, Mann NH (1997) Population dynamics of phytoplankton and viruses in a phosphate limited mesocosm and their effect on DMSP and DMS production. $\mathrm{J}$ Mar Syst (in press)

Manuscript received: October 7, 1996

Revised version accepted: March 24, 1997 